\title{
FLORA DA RESERVA DUCKE, AMAZONAS, BRASIL: LABIATAE
}

Raymond M. Harley ${ }^{1}$

Labiatae Martinov, Tekhno-Bot. Slovar. 355. 1820.

Epling, C. 1935-7. Synopsis of South American Labiatae. Repert. Spec. Nov. Regni Beih. 85: 1-341.

Epling, C. 1949. Revision del género Hyptis (Labiatae). Revista Mus. La Plata 7: 1-497.

Harley, R. M.; Atkins, S.; Budantsev, A.; Cantino, P. D.; Conn, B.; Grayer, R.; Harley, M. M.; Kok, R.; Krestovskaja, T.; Morales, A.; Paton, A. J.; Ryding, O. \& Upson, T. 2004. Labiatae. In J. W. Kadereit (ed.). The families and genera of vascular plants (K. Kubitzki, ed. in chief), vol. 7. Pp. 167-275.

Herbs, shrubs or rarely trees, usually with glands or glandular or non-glandular hairs (these simple in species from Flora area) and aromatic, stems often 4-angled. Leaves exstipulate, usually simple and opposite. Inflorescence thyrsoid, the cymes borne in the axils of bracts or upper leaves and often much modified by reduction or contraction to form false whorls (verticillasters), or forming terminal spikes, heads or capitula, or, rarely, by reduction, racemose. Bracts similar to or often markedly different from the leaves, bracteoles usually present, in capitulate inflorescences bracts or bracteoles often forming an involucre. Flowers bisexual or functionally pistillate in gynodioecious plants, or, rarely, plants dioecious. Calyx usually 5lobed, the lobes subequal to 2-lipped, with 3 posterior and 2 anterior lobes, but often modified in various ways and sometimes the upper or both lips entire; calyx 5-20-veined, corolla gamopetalous, zygomorphic and bilabiate, the posterior (upper) lip indistinctly 2 lobed to entire, falcate or straight, flat to concave or hooded, anterior (lower) lip usually \pm 3 -lobed, longer or shorter than the posterior, the median lobe flat to concave or (in
Hyptidinae) cymbiform, compressed; sometimes the corolla \pm actinomorphic. Stamens 4, adnate to the corolla, didynamous, or 2 fertile with 2 staminodes usually present, included or exserted from the corolla and often oriented towards the upper or lower lip of the corolla. Anther-thecae 2- or 1-celled, parallel or divergent, sometimes confluent, the connective sometimes extended or greatly elongated (Salvia). Ovary superior, bicarpellate and 4-ovulate, deeply 4-lobed, each lobe with a single ovule. Style usually gynobasic, shortly bifid above. Fruit of 4 (rarely fewer) usually dry nutlets, mucilaginous or not when wetted. Seeds with scanty or no endosperm.

Recent studies indicate that many genera formerly included in the Verbenaceae, would be better placed within the Lamiaceae, a situation now generally adopted (Harley et al. 2004). However, the present work maintains the traditional delimitation of these two families.

Cosmopolitan, especially frequent in warm-temperate to tropical savanna and submontane regions; $c a$. 230 genera and over 5000 species, 2 genera and 3 species in the flora area.

\section{Key to the genera of Labiatae in Reserva Ducke}

1. Nutlets cymbiform, concave on the internal face with a fimbriate, involute margin. Calyx-lobes broadly triangular, strongly reflexed in fruit. Viscous herbs with violet-blue flowers in lax heads, bracteoles not in a distinct involucre Marsypianthes

1'. Nutlets \pm ovoid, never concave. Calyx-lobes not broadly triangular, subulate or filiform. Herbs with white flowers in compact capitula with a distinct involucre of bracteoles Hyptis

${ }^{1}$ Royal Botanic Gardens, Kew, Richmond, Surrey TW9 3AB, U.K 


\section{Hyptis}

Hyptis Jacq., Collectanea 1: 101. 1786 (1787).

Mesosphaerum P. Browne, Civ. Nat.

Hist. Jamaica: 257. 1756.

Often aromatic shrubs, sub-shrubs, perennial or rarely annual herbs of various habit, stems erect to prostrate. Leaves simple to lobed or rarely pinnatifid. Inflorescence thyrsoid, of bracteate, cymose clusters of flowers, forming congested or rarely diffuse panicles, or verticillasters or capitula, these often surrounded by an involucre of bracteoles and sometimes aggregated to form pseudoracemes or spikes, bracteoles present. Flowers with calyces usually 10 -veined, with 5 usually \pm subequal lobes, these sometimes unequal or obsolescent; calyx tube straight or curved, usually strongly accrescent in fruit, rarely inflated. Corolla often white, sometimes pink-spotted on posterior lip, otherwise pink, purplish or blue, very rarely red, 2-lipped, the posterior lip 2-lobed or emarginate, the anterior lip 3-lobed, the outer lobes spreading, the median lobe cymbiform and usually compressed, with thickened hinge at base, at first enclosing the decli-nate stamens to form an explosive pollination mechanism, later becoming reflexed; corolla tube cylindrical, usually widening slightly above. Stamens 4 , declinate; anthers 2-thecous, the thecae parallel, confluent. Stylopodium absent or rarely present. Nutlets usually ovoid, but sometimes elongate or flattened.

About 290 species extending from Southern U.S.A., Mexico southwards to the Caribbean and South America, a few species extending to Africa, Asia, Australasia and the Pacific. Two species in the flora area.

\section{Key to the species of Hyptis in Rserva Ducke}

1. Leaves ovate, membranous, subglabrous to sparsely hairy beneath, with spreading hairs; petioles 5-15 mm. Stems with spreading hairs. Style jointed above the developing nutlets, the basal part (stylopodium) persistent in fruit. Fruiting capitula $c a .1 \mathrm{~cm}$ diam., on peduncles up to $c a .2 \mathrm{~cm}$ long; calyx lobes filiform, delicate, to $1.5 \mathrm{~mm}$ long 1. H. atrorubens

1'. Leaves ovate-elliptic to rarely lanceolate, somewhat coriaceous, often densely hairy beneath, hairs appressed, sometimes restricted to the veins; petioles indistinct, very short. Stems uniformly appressed-hairy. Style not jointed, falling in entirety as fruit ripens. Fruiting capitula 15-20 mm diameter on peduncles $2-7 \mathrm{~cm}$; calyx-lobes subulate, $1.5-$ $3.5 \mathrm{~mm}$ long

2. H. lantanifolia

1.1 Hyptis atrorubens Poit., Ann. Mus. Natl. Hist. Nat. 7: 466, t. 27 fig. 3. 1806. Mesosphaerum atrorubens (Poit.) Kuntze, Revis. Gen. P1. 2: 525. 1891.

Herb, 15-50 cm high with stems semiprostrate to erect, often growing through surrounding vegetation. Leaves to $3.5 \mathrm{~cm}$, ovate, aromatic, thinly hairy, with apex obtuse, base cuneate, margin regularly crenate-serrate, petiole 5-15 mm. Flowers in shortly pedunculate capitula $c a .1 \mathrm{~cm}$ diam., surrounded at the base by an involucre of broadly elliptic acuminate bracteoles, often reddish-tinged, peduncles to $2 \mathrm{~cm}$ long. Calyx-lobes filiform with broad truncate sinuses between them. Corolla white or rarely very pale lilac with small pink spots on upper lip. Style jointed above the developing nutlets, the basal part (stylopodium) persistent in fruit. Nutlets ovoid, $c a .1 \mathrm{~mm}$ long.

Mexico, Central America, West Indies, Tropical South America, West Africa.

Wet forest margins and by water. 
10.II.1995 (fl) Costa, M. A. S. \& Assunção, P. A. C. L. 139 (BM G IAN INPA K MBM UB US); 27.IV.1995 (fl) Costa, M. A. S. et al. 215 (INPA K MG MO NY R RB SP U); 26.IV.1981 (fl) Lowe, J. 4102 (INPA).

1.2 Hyptis lantanifolia Poit., Ann. Mus. Natl. Hist. Nat. 7: 468, t. 29. 1806.

Mesosphaerum lantanifolium (Poit.) Kuntze, Rev. Gen. P1. 2: 525. 1891.

Perennial herb, stems decumbent to erect, often weak-stemmed, to $80 \mathrm{~cm}$., appressed-hairy. Leaves ovate-elliptic to lanceolate, almost glabrous to densely hairy on the upper surface of the lamina, usually more densely so beneath, with conspicuous appressed hairs on the prominent veins, the base attenuate into a short petiole, longer on the lower leaves, the apex acute, margin serrulate. Flowers in often longpedunculate capitula from the axils of the 2 or 3 uppermost pairs of leaf-like bracts. Involucral bracteoles firm, ovatelanceolate, densely appressed-hairy. Calyx pale at first becoming ferrugineous, with rigid subulate teeth, sinuses narrow. Corolla white with pale lilac lobes, the upper lip spotted. Style not jointed above the nutlets, caducous from the base. Nutlets ovoid, $c a$. $1.2 \mathrm{~mm}$ long.

Widespread in the Neotropics from Mexico and the Caribbean, southwards through Central America and the Guianas to Brazil, Peru and Bolivia.

Wet forest margins and by water. 27.IV.1995 (fl) Costa, M. A. S. et al. 214 (BM G IAN INPA K MBM UB UEC US); 13.V.1996 (fl) Costa, $M$. A. S. et al. 513 (COL INPA K MG MO NY R RB SP U); 17.IV.1997 (fl) Hopkins, M. J. G. et al. 1628 (IAN INPA K SPF VEN).

In both species, a range of material, from Amazonia and elsewhere, was used to complete the descriptions of fruiting material.

\section{Marsypianthes}

Marsypianthes Mart. ex Benth., Labiat. Gen. Spec. 64. 1833.

Marsypianthus in generic conspectus, but corrected in text and index.

Perennial herbs or subshrubs, usually viscid and aromatic with softly membranous leaves, stems erect or procumbent to ascending. Inflorescences axillary, in subglobose, cymose, many- or rarely fewflowered heads. Flowers shortly pedicellate and subtended by long, curved, linear to subulate bracteoles, scarcely forming a welldefined involucre. Calyx campanulate to broadly funnel-shaped; calyx-lobes sub-equal, broadly lanceolate to triangular, spreading in fruit, not densely hairy in throat. Corolla violetblue, 2-lipped, with slender tube and \pm spreading lobes, the posterior lip 2-lobed or emarginate; the anterior lip 3-lobed, the outer lobes spreading, the median lobe saccate, hinged at base and at first enclosing the declinate stamens to form an explosive pollination mechanism, later deflexed. Stamens 4, declinate: anthers 2-thecous with parallel thecae. Nutlets ovate, smooth on outer surface, the inner concave-cymbiform with involute, fimbriate margin.

About 6 species, chiefly in Central Brazil, but with one species, extending throughout the Neotropics.

The genus can easily be recognized in fruit, the nutlets having the appearance of minute tortoises.

2.1 Marsypianthes chamaedrys (Vahl) Kuntze in Revis. Gen.Pl: 524. 1891.

Clinopodium chamaedrys Vahl, Symb., 3: 77. 1794.

Marsypianthes hyptoides Mart. ex Benth., Labiat. Gen. Spec.: 64. 1833.

Viscid herb to $75 \mathrm{~cm}$ with stems prostrate to erect, with spreading, weakly villous, often gland-tipped hairs. Leaves ovate to ovate-lanceolate, apex acute, base 
cuneate to truncate and slightly attenuate along petiole, hairy with often gland-tipped hairs, petiole 3-9 $\mathrm{mm}$. Flowers borne in pedunculate heads $1.2-2 \mathrm{~cm}$ diam., peduncles 5-17 $\mathrm{mm}$, from the axils of leaflike bracts, bracteoles very narrowly elliptic to linear or filiform, often bluish or purpletinged; calyx-tube funnel-shaped, lobes acute, broadly triangular, corolla violet-blue or pale lilac, with very small lower lip.
Fruiting calyx with lobes connivent at first, later spreading and becoming strongly reflexed to expose nutlets. Nutlets $2-3 \mathrm{~mm}$ long, dorsal surface smooth, pale, ventral surface concave and with an incurved fimbriate margin.

Throughout tropical America.

A weedy species of disturbed habitats. 3.II.1995 (bd) Costa, M. A. S. \& Nascimento, J. R. 123 (INPA K MG NY SP). 